\title{
Evaluating less-used timber species for marine construction
}

J R Williams ${ }^{1}$, G S Sawyer ${ }^{2}, S_{3}$ M Cragg ${ }^{3}$, J D Icely ${ }^{4}$, J Simm ${ }^{5}, M_{\text {Meaden }}{ }^{6}$ and L M S Borges $^{3,7}$

${ }^{1}$ Exova BM TRADA, Stocking Lane, Hughenden Valley, High Wycombe, Bucks HP14 4ND, UK

${ }^{2} 41$ Lavingdon Road, Beddington, Croydon CR0 4PQ

${ }^{3}$ Institute of Marine Sciences, School of Biological Sciences, University of Portsmouth, Ferry Road, Portsmouth PO4 9LY, UK

${ }^{4}$ Sagremarisco Lda, Apartado 21, 8650-999 Vila do Bispo, Portugal

${ }^{5} \mathrm{HR}$ Wallingford, Howberry Park, Wallingford, OX10 8BA

${ }^{6}$ Environment Agency Wales, Cambria House, 29 Newport Road, Cardiff, CF24 OTP

${ }^{7} L^{3}$ Scientific Solutions, Runder Berg 7a, 21502 Geesthacht, Germany

\section{Abstract}

Naturally durable species of timber are used as an alternative to preservative-treated timber for marine structures, but many species have not been evaluated for their potential for use in this environment. EN 275 evaluates marine borer resistance and specifies a 5-year test period: too long a period for screening tests to be economically viable. Furthermore, the test does not evaluate abrasion resistance. Novel fast-track screening methods were employed in this study to evaluate the marine borer and abrasion resistance of eighteen lesser used timber species. Comparative resistance was assessed by comparing the feeding rates of marine borers and abrasion resistance observed in candidate species against greenheart and ekki which were used as benchmark species. A number of lesser used species, originating from South America and West Africa, performed better than the benchmark species in laboratory tests and over an eighteen month exposure period in the sea. A number of species also performed comparatively well in abrasion trials although resistance to abrasion does not necessarily correlate with resistance to attack by marine borers. 
Introduction

The Environment Agency (the Agency) and other Maritime Coastal Authorities fund, build and maintain timber structures in the marine environment throughout the United Kingdom, a particular focus being groynes for control of longshore transport of beach material. For such structures, historically, timber has been favoured as a construction material although construction has relied upon a narrow range of timber species such as greenheart (Chlorocardium rodiel) and ekki (Lophira alata). The Agency has concerns that this industry sector has become over-reliant on the use of these two species and fears that it may become increasingly difficult to procure these two species in sufficient volumes and sizes.

Another challenge is being able to procure these species with supporting evidence of sustainability and legality that satisfies its timber purchasing policy. Illegal logging and unsustainable forest management are now recognised as a global problem. Forests are a precious natural resource, and their destruction has wide- ranging social, economic and environmental impacts. However, there is demand for strong, durable, cost-effective and environmentally acceptable construction material (Environment Agency 2010A). With this difficulty in mind, the Agency has also recognised that alternatives to timber, such as steel, steel-reinforced concrete or rock for example, may have to be considered for construction schemes (Environment Agency 2010B).

In order to widen their inventory of suitable timber species, the Agency, in collaboration with $\mathrm{H}$ R Wallingford and the Timber Research and Development Association (TRADA), undertook a research project to assess the potential marine borer and abrasion resistance of candidate lesser used species (LUS) of timber using a range of novel, fast-track laboratory screening tests, as well as a marine exposure trial. Candidates were identified by desk-based scoping study and previous research (Borges et al. 2003; Crossman and Simm, 2004 and Williams et al. 2004A).

Engineers have a key role in making informed decisions on the type of materials to be used in the coastal schemes they design and construct. The decision must balance technical requirements with environmental and cost considerations (Williams et al 2004A and Environment Agency, 2010B).

Economics are an important consideration for all coastal schemes. Practically all major capital schemes, such as the current $£ 17$ million groyne-renewal programme at 
Bournemouth, are dependent upon public money. The local authority must strike a balance between the most suitable material for the job against monies available (Cowen 1979). This is even more challenging in the current climate of austerity where scheme designers must find $10 \%$ efficiency savings (pers. comm. Harlow 2015).

Securing public money for such schemes is a lengthy, competitive process. For example, in securing funding for a coastal protection scheme, the local authority must comply with a Shoreline Management Plan and a Strategy Study which pose the questions "what should we do with this management unit?" (e.g. hold the line, retreat the line, advance the line or do-nothing) and "how do we do that?". The project appraisal must include a detailed design of all the options, the economic case for the works and comply with all Formal Notices under the Coast Protection Act 1949. If it is approved technically and economically, the scheme can go ahead (pers. comm. Harlow 2015).

The marine environment is challenging for all construction materials but timber suffers remarkably little from the effects of immersion compared to, for example, concrete, which can suffer from spalling, and steel which can suffer from corrosion (Cragg 1996).

From a technical point of view, timber retains attractions over other materials due to its relative durability (Cragg 1996), resilience and favourable strength-to-weight ratio, ease of fabrication and repair. Environmentally, the renewable nature of timber is attractive, particularly if recycled or obtained from well-managed forests (Crossman and Simm 2003). However, material costs, the proven track record of timber species, the risk of marine borer attack and the requirement to meet stringent procurement rules may discourage engineers from its use (Williams et al 2004B).

Consequently, this sector of the construction industry is conservative and there is a reluctance to specify timber species without a proven track record. Brazier (1995) summarised the desirable material properties desirable for timbers used in marine construction as being: resistance against marine borers and fungal attack in the marine environment; resistance to the scouring action of beach material striking the structure; good strength properties, the ability to withstand sudden impact and deflection under load and availability in cross section sizes of $300 \mathrm{~mm} \times 300 \mathrm{~mm}$ or greater and, often, lengths up to $15 \mathrm{~m}$. 
Historically, the combination of the above factors has resulted in use of a short list of tropical hardwoods. Engineers have almost always chosen a dense, naturally durable timber with a proven track record, such as greenheart or ekki, although a few other dense tropical hardwoods such as balau (Shorea spp.), opepe (Nauclea diderrichii) and karri (Eucalyptyus diversicolor) have also been used. The disadvantage of this conservatism is that commercial exploitation of such a narrow range of timbers can accelerate their depletion and inflate the price of certain tropical timbers (Environment Agency 2010B).

Marketing LUS in a conservative market place has always tested the timber industry. End-user resistance to these LUS by engineers being driven by a lack of (readilyavailable) information about their technical properties. Two of the principal obstacles in using lesser-known species are that, either there is limited confidence in the pedigree of the technical information about these species, or little is known about their resistance to marine borer attack (Williams et al 2004B). It should be borne in mind that high natural durability in terrestrial conditions does not necessarily guarantee robust marine performance (Cragg 1996).

\section{Hazards of the marine environment}

Timber that is exposed in the marine environment below the high tide mark is subject to attack by marine bacteria, fungi and wood boring animals. Marine wood borers are an heteregeneous group of wood feeding organisms, including the Teredinidae (Distel, 2003) and Limnoriidae (Cragg, 2003).

The most economically important wood boring Crustacea in European waters belong to the Limnoriidae, isopods commonly known as gribbles which can cause significant damage to timber in the marine environment (Cragg 2003, Borges et al 2014 A, B and Castello 2011). Wood boring limnoriids have evolved two key adaptations to use wood as substrate. The first was the ability to tunnel into timber for protection. The second adaptation was to use timber as a food source (Kern at al 2013).

Marine wood boring Teredinidae (commonly known as shipworms or teredinids) occur in almost all aquatic ecosystems from tropical to cold-temperate waters (Turner, 1966). At least nine wood-boring teredinids have been reported so far in European coastal waters (Borges et al., 2014A). 
Teredinids are estimated to cause over one billion dollars' worth of damage to submerged wooden structures per annum (Shipway et al 2014) and the introduction of shipworms into new areas is often followed by rapid and extensive destruction (Turner 1966, Cohen and Carlton 1995 and Distel et al. 2011). The animals may cause severe damage to a timber structure over a comparatively short space of time.

Climate change has been causing a shift in the geographical range of species of marine borers (Parmesan and Yohe, 2003) but the effect of sea surface warming is still poorly understood in marine systems (Rivadeneira and Fernandez, 2005). Therefore, the impact of global warming also needs to be considered in relation to teredinid and limnoriid activity.

Increases in temperature and salinity have been reported in the Mediterranean (Gibelin and De'que' 2003; Sanchez and Gallardo 2004). On the Portuguese coast the raising of sea surface temperatures and salinity have been affecting the intertidal species range of marine borers (Borges et al 2010). Increases in sea temperature and salinity are expected to continue over the coming decades (Giorgi and Lionello 2008; Giannakopoulos and Le Sager 2009) and are known to extend teredinid distribution ranges (Borges et al 2010; Borges et al., 2014A,B, Paalvast and van der Velde 2011 and Shipway et al 2014) and are likely to increase the vigour of limnoriids. Furthermore, warmer temperatures are known to accelerate growth and to increase boring activity. Therefore, the risk posed by marine borers will become more severe due to global warming.

With reference to the coastal waters around the UK and based upon previous TRADA research carried out in the 1960's (Hall and Saunders 1967), there are two main groups of marine borers and these are the teredinids and limnoriids. Limnoriids are ubiquitous whereas teredinids have previously been limited to the south coast and isolated estuarine areas along the west coast of the UK (Hall and Saunders 1967). Plaster and Sawyer (1998) identified that changes in the species of marine borers, their distribution and occurrence in marine structures around the UK coastline should be investigated due to improving water quality and predicted climate change. It should be noted that since 1967 there has not been a comprehensive survey of the UK coast for marine borer activity and on the basis of evidence collated by Borges et al (2014 A, B) changing environmental conditions do appear to affect marine borer 
distribution and activity. The research cited above indicates that climate change may increase the risk of marine borers attacking timber structures around the UK coastline.

Moreover, anticipated increases in water temperature and estuarine salinity (Paalvast and van der Velde 2014) have the potential to increase the vigour of these populations and to allow new species to invade. Furthermore, environmental legislation has led to a vast and continuing improvement in water quality which has enabled marine borer populations to flourish in harbour areas where pollution had previously excluded them (Eaton and Hale 1993). Therefore, it is reasonable to surmise that the risks associated with marine borers are only going to increase in the future.

The distribution of limnoriids (Figure 1) is controlled by environmental and biological factors as well as the presence of wood. The most important environmental factors controlling the distribution and survival of limnoriids are temperature and salinity (Eltringham 1971 and Borges et al 2009). Temperature and salinity influence the boring activity, the feeding rates of limnoriids (Borges et al. 2009). Temperature is particularly important during the reproductive and migratory season (Eltringham 1971).

The life history strategy helps explain the distribution of limnoriids. These organisms have low fecundity (Cragg 2003) and tend to form large colonies in the more sheltered parts of timber structures. In temperate waters, swarming of the animals tends to occur in the spring although additional swarming may occur in the autumn. They inhabit the surface of timber and they are fully mobile (Eaton and Hale 1993) and tend to concentrate at the intertidal zone. They are very small animals, just about visible to the human eye when timber is inspected in situ. Attack by limnoriids tends to be superficial and results in the creation of an extensive network of galleries at or just below the wood surface. In softwoods, the animals favour the less dense earlywood which can rapidly lead to the timber forming wafer-like plates (Eaton and Hale 1993).

Limnoriids tend to be sensitive to their environment and can cause significant damage in harbours and estuarine environments characterised by waisting of the 
timber (Figure 2). However, where structures are exposed to the full force of the sea and where there is a high risk of mechanical abrasion, limnoriids find it difficult to establish large populations. This is because the abrasive nature of the environment destroys the galleries. In such instances, limnoriids tend to be restricted to the sheltered parts of structures, particularly where joints are formed as these can provide suitable refugia for the animals (Perscomm Harlow 2015).

Teredinids (Figure 3) are highly specialised bivalves characterised by elongated bodies and a greatly reduced shell, adaptations which facilitates their wood boring life style (Turner 1966). Unlike the limnorids, the adults are sessile and the animal remains in the same tunnel throughout its life. Each tunnel is discrete and the animals avoid intruding into neighbouring tunnels as they grow and excavate into the timber. In warm waters some animals can grow in excess of one or two metres (Eaton and Hale 1993).

Even in timbers of limited volume, teredinids will not emerge from the timber and will continue to bore alongside its neighbours until the timber is more or less destroyed and breaks apart (Eaton and Hale 1993, and Shipway et al 2014). Teredinids line their tunnels with a secretion of calcium carbonate. The posterior part of the animal maintains contact with the external seawater environment via a fine hole generally less than $1 \mathrm{~mm}$ in diameter in diameter. This hole is the only external sign that shipworm have colonised a timber component which makes surveying for teredinids extremely difficult in situ. They are capable of causing extensive damage (Figure 4). 
Figure 1: Specimens of Limnoria quadripunctata. Ventral view.

Figure 2: Waisting of timber pile, i.e. it develops a waist (or a pencil point shape) in the intertidal zone, caused by limnoriid attack. Note that there is no attack below the sea bed line which is indicated by the arrow. 
Figure 3: Teredinid extracted from a Douglas fir waling of the Barmouth viaduct within the intertidal zone of the estuary mouth of the River Mawddach, Gwynedd.

Figure 4: Example of the typical damage caused by teredinids. 
Materials

Eighteen LUS were selected for assessment on the basis of previous indicative laboratory and marine trials (Borges et al. 2003, Crossman and Simm 2004 and Williams et al. 2004A), their commercial availability in suitable section sizes, volumes, price and evidence of legality and sustainability. The regions of origin of the candidate LUS, benchmark and well known timbers are presented in Tables 1 and 2 along with the reference codes used to identify the timbers throughout marine exposure trials.

Table 1: List of lesser used timber species selected for evaluation.

\begin{tabular}{|c|c|c|c|c|}
\hline Commercial name & Botanical name & $\begin{array}{l}\text { Region of } \\
\text { origin }\end{array}$ & Supplier & $\begin{array}{l}\text { Reference } \\
\text { Code }\end{array}$ \\
\hline Angelim vermelho & Dinizia excelsa. & South America & EcoChoice Ltd & AV \\
\hline Basrolocus & Dicoryia guianensis & South America & EcoChoice Ltd & $\mathrm{BA}$ \\
\hline Cloeziana & Eucalyptus cloeziana & South Africa & EcoChoice Ltd & $\mathrm{CL}$ \\
\hline Cupiuba & Goupia glabra & South America & EcoChoice Ltd & $\mathrm{CU}$ \\
\hline Dabema (dahoma) & $\begin{array}{l}\text { Piptadeniastrum } \\
\text { africanum }\end{array}$ & West Africa & EcoChoice Ltd & $\mathrm{DA}$ \\
\hline Evuess (kruma) & Klainidoxa gabonensis & West Africa & EcoChoice Ltd & EV \\
\hline Garapa & Apuleia leiocarpa & South America & EcoChoice Ltd & GA \\
\hline Massaranduba & Manilkara spp & South America & EcoChoice Ltd & MA \\
\hline Mora & Mora excelsa & South America & $\begin{array}{l}\text { Aitken and } \\
\text { Howard Ltd }\end{array}$ & MO \\
\hline Mukulungu & Autronella congoensis & West Africa & EcoChoice Ltd & MU \\
\hline Niove & Staudtia kamerunensis & West Africa & EcoChoice Ltd & $\mathrm{NI}$ \\
\hline Okan (denya) & Cylicodiscus gabunensis & West Africa & EcoChoice Ltd & OK \\
\hline Piquia & Caryocar spp. & South America & EcoChoice Ltd & $\mathrm{PI}$ \\
\hline Sapucaia & Lecythis paraensis & South America & EcoChoice Ltd & SA \\
\hline Souge & Parinari excelsa & West Africa & EcoChoice Ltd & SO \\
\hline Tali & Erythrophleum ivorense & West Africa & EcoChoice Ltd & TA \\
\hline Tatajuba & Bagassa spp. & South America & EcoChoice Ltd & TJ \\
\hline Timborana & $\begin{array}{l}\text { Enterolobium } \\
\text { schomburgkii }\end{array}$ & South America & EcoChoice Ltd & $\mathrm{TI}$ \\
\hline
\end{tabular}


Table 2: List of timber species with a known track record for use in marine construction including benchmark and control species.

\begin{tabular}{|l|l|l|l|l|}
\hline Commercial name & Botanical name & $\begin{array}{l}\text { Region of } \\
\text { origin }\end{array}$ & Supplier & $\begin{array}{l}\text { Reference } \\
\text { code }\end{array}$ \\
\hline Yellow Balau & Shorea spp. & Sabah) & $\begin{array}{l}\text { Aitken and } \\
\text { Howard Ltd }\end{array}$ & BU \\
\hline Douglas fir & Pseudotsuga menziessii & North America & $\begin{array}{l}\text { Aitken and } \\
\text { Howard Ltd }\end{array}$ & DF \\
\hline Bilinga & Nauclea diderrichii & West Africa & EcoChoice Ltd & BI \\
\hline Ekki & Lophira alata & West Africa & $\begin{array}{l}\text { Aitken and } \\
\text { Howard Ltd }\end{array}$ & E \\
\hline Greenheart & Chlorocardium rodiei & Guyana & $\begin{array}{l}\text { Aitken and } \\
\text { Howard Ltd }\end{array}$ & GH \\
\hline Karri & Eucalyptus diversicolor & Australia & $\begin{array}{l}\text { Aitken and } \\
\text { Howard Ltd }\end{array}$ & KA \\
\hline Oak & Quercus spp. & Europe & $\begin{array}{l}\text { Aitken and } \\
\text { Howard Ltd }\end{array}$ & AL \\
\hline Opepe & Nauclea diderrichii & West Africa & $\begin{array}{l}\text { Aitken and } \\
\text { Howard Ltd }\end{array}$ & OP \\
\hline Purpleheart & Peltogyne spp. & South America & $\begin{array}{l}\text { Aitken and } \\
\text { Howard Ltd }\end{array}$ & $\begin{array}{l}\text { PRADA } \\
\text { Technology }\end{array}$ \\
\hline European redwood & Pinus sylvestris & $\begin{array}{l}\text { Western } \\
\text { Europe }\end{array}$ & SP \\
\hline
\end{tabular}

Ekki and greenheart are emboldened to highlight their importance as the benchmarking timbers. The sapwood of European redwood (Pinus sylvestris), also emboldened, was used for control purposes to confirm the vigour of the marine borers during the laboratory and marine trials and also to validate the experimental data. European oak (Quercus spp.) was included in the project on the basis that it is a commercially important, naturally durable European hardwood. Other tropical timbers, well known for their use in the marine environment and/or their natural durability listed in Table 2 were selected for comparative purposes.

Stock material was selected at random by both suppliers where a reasonable attempt was made to ensure that the selected boards were widely dispersed within a timber parcel or parcels so that the natural variability of timber within commercial supplies was reproduced. Ten boards comprising stock material of dimensions approximately $25 \mathrm{~mm} \times 125 \mathrm{~mm} \times 500 \mathrm{~mm}$ were provided by the timber suppliers for each timber species. One small specimen was cut from one of the boards of each species so that the species/genus could be confirmed using microscopic techniques. 
It should be noted that in almost all cases, identification down to genus level was possible. However, it was not practicable to identify individual species as most commercial timbers comprise groups of species. However, on the basis of examination of the microscopic properties and consideration of the physical properties of the specimens, all candidates matched their reported commercial names.

\section{$4 \quad$ Methods}

Fast track novel laboratory screening trials to determine comparative marine borer and abrasion resistance have been devised by University of Portsmouth and the Forest Products Research Laboratory (Borges et al. 2008 and Sawyer and Williams 2005) to respectively assess the feasibility of determining limnoriid and abrasion resistance. However, marine exposure trials are still required to determine comparative resistance to teredinid attack due to the difficulty of maintaining viable teredinid populations under laboratory conditions. The rationale behind both laboratory trials was "if it fails in the laboratory then it is likely to fail in the sea" and that these trials could filter out poor performing timbers before progressing to more expensive, time consuming marine exposure trials.

\subsection{Investigating limnoriid resistance}

Faecal pellet production rate of gribble matches feeding or ingestion rate quite closely and it is much easier to measure than wood loss by ingestion. The approach used in this investigation takes advantage of this situation. The method described in this report has been developed from investigations of feeding biology of these organisms (Wykes et al., 1997) and evaluation of test conditions for this method (Praël et al., 1999, Borges et al 2009) and implemented in previous research undertaken by Borges et al. (2003 and 2008). Their research demonstrated that determining limnoriid resistance in fast track laboratory trials was reliable and the methods used follows that of these authors closely.

Specimens of Limnoria quadripunctata Holthuis were obtained from a laboratory population that was maintained in blocks of European redwood kept in running seawater from Langstone Harbour near Portsmouth, UK. Animals were transferred to a cell culture dish using a fine sable brush or fine forceps.

Trial specimens were sticks measuring $20 \mathrm{~mm} \times 4.5 \mathrm{~mm} \times 2 \mathrm{~mm}$ prepared from the stock material. Heartwood was used in all cases except for the control timber 
(European redwood) for which sapwood was used. The vigour and health of the animals was assessed and confirmed by observing feeding rates on the sapwood blocks prior to the starting the trials. Confirmation of high feeding rates on sticks of European redwood sapwood validated the experiment.

Prior to experimentation, the sticks were leached in seawater for one week, with a change of water after three days to remove water-soluble extractives that were not relevant to long term performance of naturally durable timbers. Each stick was placed into $4 \mathrm{ml}$ of seawater in each chamber of a cell culture box containing 12 chambers measuring $20 \mathrm{~mm}$ in diameter. The cell culture dishes were kept in the laboratory under ambient lighting conditions at $20 \pm 2^{\circ} \mathrm{C}$ for 28 days.

One animal was placed into each well of each dish. After half a week, animals and sticks were carefully transferred to matching cell culture dishes with fresh seawater and the number of faecal pellets left in the original dishes was counted using image analysis software (ImageJ: http://imagej.net/Donloads) to analyse digital macro images of the chambers viewed from above and illuminated from below using a stereo microscope. Figures 5 and 6 illustrate typically low and high feeding rates that were observed.

Figure 5: Low feeding rate observed in a chamber containing a stick of ekki and a limnoriid. In this case, ingestion of wood has killed the limnoriid. 
Figure 6: High feeding rate observed in a chamber containing a stick of European redwood sapwood which confirmed the vigour of the limnoriid population.

The rationale behind this laboratory test is that faecal pellet production rate matches feeding or ingestion rate quite closely. A one-way analysis of variance (ANOVA) was performed with Dunnet's post-hoc test to identify:

1. Timbers for which feeding rates were significantly lower than on ekki.

2. Timbers for which feeding rates were significantly lower than on greenheart.

3. Timbers for which feeding rates were significantly higher than on ekki.

4. Timbers for which feeding rates were significantly higher than on greenheart.

Results were presented as average daily feeding rates and these were compared against results obtained for the two benchmark timbers, greenheart and ekki.

\subsection{Investigating abrasion resistance}

Test blocks were prepared from the timber species listed in Tables 1 and 2 for testing by immersion in running sea water for four weeks to become saturated. Moisture meter checks with calibrated electrical resistance type moisture meter indicated that all blocks were above fibre saturation point with readings in test blocks in excess of $30 \%$. Fibre saturation point is a theoretical state where the wood cell walls are fully 
saturated with water and the cavities are empty. Typically, this value is approximately $27 \%$ (Desch and Dinwoodie 1996). The fibre saturation point can be influenced by density. The fibre saturation point deceases with increasing density (Skaar 1988). Immediately prior to testing, the volume of the blocks was measured by displacement in an eureka can. Fresh water displaced by the blocks was weighed directly.

A total of six test specimens per species were prepared. Each block was drilled centrally with a $8 \mathrm{~mm}$ hole for securing to the test frames as illustrated in Figure 7. The testing machine used was adapted from a Los Angeles aggregate fragmentation resistance apparatus. This comprised a heavy robust steel drum that can be sealed so as to be watertight. The speed of rotation had been determined from previous research (Sawyer and Williams 2005) and was $33 \mathrm{rpm}$. The testing regime used an initial charge of $25 \mathrm{~kg}$ of $20 \mathrm{~mm}$ flint shingle with 15 litres of seawater to ensure a consistent abrasive environment.

After 80,000 revolutions, the shingle was emptied and thoroughly flushed. Fresh shingle and seawater was loaded and the machine run for a further 80,000 revolutions. In this way, each test had a duration of 5 days. At the completion of testing, all blocks were thoroughly washed and cleaned and stored under water to prevent drying. Finally the volume loss of blocks was determined by the displacement method. Figure 8 illustrates typical erosion of the specimens. 
Figure 7: Typical test frame illustrating the arrangement of test blocks prior to the start of the experiment.

Figure 8: A test frame holding eroded greenheart test blocks after 160,000 revolutions. 
The arrangement of the LUS test blocks on the racks followed a latin square distribution so that each timber was replicated at all the rack positions. The variation in volume loss between different candidate timbers was examined with a GLM ANOVA, with candidate timber and position on rack as fixed factors. Dunnet's post hoc test was carried out to identify:

1. Timbers that performed significantly better than ekki

2. Timbers that performed significantly better than greenheart

3. Timbers that performed significantly worse than ekki

4. Timbers that performed significantly worse than greenheart

\subsection{Investigating teredinid resistance}

The test site for the marine exposure trial was located in Olhão harbour on the Ria Formosa lagoon, Portugal. The conditions in the Ria Formosa lagoon support well within the environmental limits described by Borges et al (2014A) that will support marine boring organisms.

The tidal regime at this location is semi-diurnal with a range of $1.35 \mathrm{~m}$ on neap tides to $3 \mathrm{~m}$ on spring tides. Although the lagoon is on the Atlantic coast, the climatic conditions are essentially Mediterranean with hot dry summers and warm wet winters. The average temperatures and salinities of the lagoon water at Olhão (Newton and Mudge, 2003) range between $12^{\circ} \mathrm{C}$ and $28^{\circ} \mathrm{C}$ and $33-36.5 \mathrm{psu}$, respectively. Previous research by Williams et al. (2004A) reported the presence of aggressive teredinid and limnioriid attack on vulnerable timbers.

Six specimens of each timber were cut to dimensions of $20 \mathrm{~mm} \times 75 \mathrm{~mm} \times 300 \mathrm{~mm}$ and were prepared for immersion. European redwood sapwood was used for control purposes and to assess the vigour of borer activity. EN 275 requires that samples are arranged vertically. The test method in this trial was an improvement on EN 275 as the racks were immersed horizontally which ensured that all samples were exposed to the same tidal marine conditions, with the samples orientated vertically. The test racks were weighted and suspended approximately $0.5 \mathrm{~m}$ from the sea bed. Figure 9 illustrates a typical test rack and Figure 10 illustrates the test site. 
The marine exposure trial lasted for 18 months, from March 2008 to September 2009. Three assessment visits were made to monitor performance. During each assessment visit, the racks and samples were cleaned of all marine fouling. This was to ensure that calcareous surface growths could not influence interpretation of the $X$ ray photographs. After cleaning, the specimens were examined for signs of attack by marine borers. Figures 9 and 10 illustrate examples of test racks before and after cleaning.

Figure 9: Typical marine fouling on a test racks after six months immersion.

Figure 10: General appearance of a test rack after cleaning to facilitate $X$ ray photography. 
The racks were then wrapped in polyethylene bags to prevent stress to teredinid populations in the timber samples caused by drying out of the timber during transportation between the test site and a local X-ray clinic. The duration between removal from the site and re-immersion following $X$-ray photography was no more than 24 hours. Teredinid attack was assessed using the visual assessment categories detailed Table 4, based on the methodology given in BS EN 275 (1992). The whole specimen was assessed with the exception of the timber coincident with the frames which absorbed the X-rays. The exposure variables were determined by the equipment used, but images were a good indication of the desired result so $\mathrm{X}$-ray exposure was determined by trial and error.

Table 4: Visual assessment categories (continuous, non-linear scale) used to estimate teredinid borer attack.

\begin{tabular}{|c|c|}
\hline $\begin{array}{l}\text { Numerical assessment } \\
\text { category }\end{array}$ & $\begin{array}{c}\text { Amount of attack caused by teredinid as } \% \text { board } \\
\text { volume }\end{array}$ \\
\hline 0 & No attack. \\
\hline 1 & $\begin{array}{l}\text { Minor attack. Single or a few scattered tunnels not } \\
\text { covering more than } 10 \% \text { of the specimen areas as it } \\
\text { appears on X-ray film. }\end{array}$ \\
\hline 2 & $\begin{array}{l}\text { Moderate attack. Tunnels not covering more than } 25 \% \text { of } \\
\text { the specimen area as it appears on X-ray film. }\end{array}$ \\
\hline 3 & $\begin{array}{l}\text { Severe attack. Tunnels covering between } 25 \%-50 \% \\
\text { of the area of the specimen as it appears on X-ray film. }\end{array}$ \\
\hline 4 & $\begin{array}{l}\text { Failure. Tunnels covering more than } 50 \% \text { of the area of } \\
\text { the specimen as it appears on X-ray film. }\end{array}$ \\
\hline
\end{tabular}

For each timber, the visual assessment ratings for each test sample were added and the result divided by the number of test samples to yield a notional average rating. As results for the marine exposure trial were reported in terms of an arbitrary scale (a practical and widely used approach for field trials with timber), a parametric statistical approach is not appropriate so standard error (S.E.) values were not quoted.

\section{$5 \quad$ Results}

\subsection{Resistance to limnoriids}

The data in Figure 11 presents pellet production rate per day over a 28 day period (mean \pm standard error). Significantly lower feeding rates than those recorded on 
both benchmark timbers (greenheart and ekki) were recorded on niove (Staudtia kamerunensis), balau and cupuiba (Goupia glabra). Significantly higher feeding rates than both benchmark timbers were recorded on purpleheart (Peltogyne spp.), mukulungu (Autronella congoensis), eveuss (Klanidoxa gabonensis) and European redwood (Scots pine/ Pinus sylvestris). Significantly higher rates than that recorded for greenheart alone were recorded on European oak, tali (Erythrophleum ivorense) and angelim vermelho (Dinizia excelsa).

Figure 11: Average daily feeding rates of limnoriids recorded on test timbers. 


\subsection{Resistance to abrasion}

The data in Figure 12 presents average loss in volume of the timber species. Comparison of abrasion data is presented as a measure of mean volume loss ( \pm Standard Error) of the timbers against the mean volume loss measured for ekki and greenheart. With reference to ekki, none of the candidate timbers indicated that they performed significantly better and eighteen out of twenty six species (greenheart to balau on Figure 12) performed significantly worse than ekki when challenged with shingle. With reference to greenheart, souge (Parinari excels), oak, eveuss and ekki indicated that they performed significantly better during this trial. Only cupiuba, opepe, massaranduba (Manilkara spp.), bilinga (Nauclea diderrichil) and yellow balau performed significantly worse than greenheart.

Figure 12: Average loss in volume recorded on test timbers. 


\subsection{Resistance to teredinids}

The data in Figure 13 presents the mean visual assessment ratings recorded on all timber species exposed during the 18 month marine trial period. The failure of the sapwood control blocks demonstrated that the test site has aggressive teredinid populations. Furthermore, oak, Douglas fir (Pseudotsuga menziessii), karri, mora (Mora excelsa) and purpleheart also yielded a maximum mean visual assessment rating of 4.0 .

Figure 13: Mean visual assessment ratings recorded after18 months exposure. 


\subsection{Resistance to limnoriids}

The sapwood of European redwood was used as a control to validate the experiment. Comparatively high daily feeding rates observed on sapwood confirmed the vigour of the test organisms and validated this laboratory trial.

Comparison of timber performance, expressed as suppression of feeding rates, against the benchmark species greenheart and ekki provides an indication of their comparative resistance to limnoriid attack. From a benchmarking point of view it can be seen that if significant differences in performance to greenheart are chosen as a selection threshold then a comparatively high number of candidate species would be rejected at this stage. However, if significant differences in performance to ekki are used as the selection threshold, then only purpleheart, mukulungu and evuess would be considered for rejection at the screening stage. Given that ekki is one of the favoured timbers used for marine and freshwater construction, it would be reasonable to use ekki as the benchmarking species on the basis of these results alone.

The one way analysis of variance (ANOVA) identified a number of LUS of timber as performing significantly better than ekki and greenheart. It should be borne in mind that good resistance to limnoriids does not necessarily mean that the timbers will have good resistance to attack by teredinids.

\subsection{Resistance to abrasion}

The sapwood of European redwood was not included in the abrasion trials as a control as there was no requirement to validate the vigour of test organisms in this instance. However, Douglas fir was included as a reference timber because it is a commercially important softwood that is used for marine construction. Furthermore, there is anecdotal evidence to suggest that Douglas fir performs better than some denser, harder tropical hardwoods as the less dense softwood 
structure can act as a shock absorber which more efficiently dissipates the energy expended on the timber surface under shingle impact.

The effects of abrasion in marine trials are difficult to study owing to the extreme variability of weather and site conditions and existing laboratory methods also bear little resemblance to the effects of marine abrasion. In relation to abrasion, it should be noted that Oliver and Woods (1959) undertook an investigation to determine the rates of wear by shingle abrasion of a number of timber species used as piles and planking in sea defence groynes. Their study spanned a six year period (19531959). Again, projects of this duration are too long to be commercially practicable. Other than the work of Oliver and Woods, a previous search of the literature by Sawyer and Williams (2005) found that there had been little other research on the resistance of marine timbers to the effects of marine abrasion. The abrasion tests exposed the timbers to 160,000 revolutions. If we assume that timber in situ is exposed to 6 waves every minute, it follows that the structure will be exposed to 360 waves per hour.

On the basis of these assumptions and in the absence of other information, the test of 160,000 cycles would therefore equate to about 450 tides. It is unlikely that all waves will have sufficient energy to subject the structure to abrasion with every wave cycle. Therefore, a second assumption has to be made that the waves will only generate abrasive conditions for 33 percent of the time. This would then equate to 1350 tides or about 675 days. The abrasion tests described in this report have therefore condensed 675 days in service (almost two years) into a 5 day test period. However, it should be borne in mind that direct comparisons to exposure in situ are difficult to make and the assumptions detailed above could be viewed as indicative and provides a means to predict comparative abrasion resistance of LUS used in groyne structures in the intertidal zone on a shingle beach.

From a benchmarking point of view, it can be seen that if a significant difference in performance compared to greenheart is chosen as a selection threshold then three LUS timbers performed significantly better than greenheart. These were tali, eveuss, and souge. However, if ekki is chosen as a selection threshold, all candidate species would be rejected at this stage as none performed significantly better than ekki if abrasion is the principal material property required by the design engineer. 
It is possible that different results could be obtained if the candidate timbers were exposed to sand abrasion. However shingle was selected on the basis that it provided the worst case scenario.

\subsection{Resistance to teredinids}

Statistical analysis using ANOVA was not possible with the data obtained from the marine exposure trial as a non - linear visual assessment scale has been used. The visual assessment rating scale has been developed to identify shipworm resistance towards the lower end of the scale so that differences between ratings of 1.0 and 2.0 are easily distinguishable in the field. The visual assessment scheme described in Table 4 is skewed towards the lower end of the assessment scale. This is because it is important to separate those samples with less than $10 \%$ colonisation and those with $10 \%-25 \%$ colonisation. It is this area where the interpretation of results may provide the basis for differentiating timber species which may be classified as being resistant to teredindid attack (less than $10 \%$ colonisation) and moderately resistant (10\%-25\% colonisation).

Greater than $25 \%$ colonisation indicates severe attack. There is little point in defining differences above this threshold level as the timber species with a rating above this level may be considered as not having any practical resistance to teredinid attack.

The effective use of $\mathrm{X}$-radiography as a method of assessment relies upon thorough cleaning of the timber samples as the remnants of calcareous material can lead to misinterpretation with the early stages of colonisation by teredinids. As the trials progress, the juvenile teredinids grow and extend their tunnels. As they grow they become more distinctive when assessed using X-radiography. As a consequence, small variations in the mean visual assessment ratings of candidate timber during the early stages of the trial may occur due to juvenile mortality. Figure 14 illustrates severe teredinids attack clearly illustrated by extensive tunnelling and Figure 15 illustrates good resistance to shipworm attack as illustrated by the lack of tunnels in the specimen. 
Figure 14: Extensive teredinid attack in a control specimen of European redwood of detected by X-ray photography. The extensive damage confirms the presence of an aggressive teredinid population in the Ria Formosa lagoon and validates the marine trial.

Figure 15: No evidence of teredinid attack in a specimen of the LUS angelim vermelho. 
After 18 months exposure in a hazardous marine environment, the following candidate timbers performed comparably to ekki and greenheart, in that no shipworm attack was detected in them: angelim vermelho, basralocus (Dicoyria guianensis), okan (Cyclodiscus gabunensis) and tali.

Those timbers exhibiting minor attack by shipworm were cupiuba, eveuss, garapa (Apuleia leiocarpa), massaranduba (Manilkara spp.), piquia (Caryocar spp.), sapucaia (Lecythis paraensis), souge and timborana (Enterolobium schomburgkii). However, after 18 months exposure, the mean visual assessment ratings of these timbers was still less than 1.0 which indicated that these candidate timbers may be considered as resistant to attack by teredinds, despite performing slightly worse than greenheart and ekki.

Only dabema (Piptadeniastrum africanum) and mukulungu were considered as being moderately resistant to teredinid attack. In this particular trial, those timber species that yielded a mean visual assessment rating in excess of 2.0 were considered to have little resistance to attack by teredinids. The timbers that fall into this category are cloeziana (Eucalyptus cloeziana), mora, niove and tatajuba (Bagassa spp.).

\section{Conclusions}

Marketing LUS has always tested the timber industry and there has often been considerable end-user resistance to working with LUS as their technical properties are not fully appreciated. The data and conclusions contained within this paper should begin to erode this conservatism and encourage the use of a wider range of LUS in marine applications and contribute towards the goal of profitable forestry and sustained timber yield management. If value can be added to a tropical forest for timber production then it may come under less pressure for conversion to other uses.

However, the acceptance of LUS will require a holistic approach where in addition to considering marine borer resistance, abrasion resistance, other factors such as strength, price, section sizes, shrinkage, movement in service, workability and machinability characteristics, and delivery times may influence choice.

Selection of timber by understanding service requirements and hazards may provide a means to introduce LUS into marine construction. In other words, the functional performance of a timber and its ability to withstand the most dominant site-specific 
hazards, whether resistance to limnoriids, teredinids or abrasion, could drive the selection of LUS.

Selection by this means could be undertaken with the full support of an examination and assessment regime whereby the performance of these timbers can be monitored over their service life so reliable data from an asset management point of view may be collated. Of course, this requires a long term vision. Three LUS, tali, souge and evuess have been installed on beach groynes at Pevensey Bay in 2009, as part of an Environment Agency project. The performance of these species has been evaluated in Spring 2016.

The screening programmes described on this paper provide an effective mechanism for the rapid evaluation of both the marine borer and abrasion resistance of LUS. However, the screening test described in this paper do not solve the significant problem of determining the strength properties of LUS. Confidence in strength properties is a critical factor that engineers require when specifying timber and a dearth of reliable information regarding the strength of LUS is one of the major obstacles in preventing their use. Strength test programmes require significant investment.

Historically, there has been considerable end-user resistance to using LUS as their technical properties are not fully appreciated. The conclusions that identify the technical properties of a range of LUS presented in this paper may begin to encourage the use of a wider range of lesser used timbers. The research also provides robust evidence to justify investment in testing programmes to determine the characteristic values for bending strength, modulus of elasticity and density using the requirements of BS EN 384 and BE EN 408. 


\section{References}

Borges, L. M. S., Cragg, S. M. and Williams, J. R. (2003) Comparing the resistance of a number of lesser known species of tropical hardwoods to the marine borer Limnoria using a short term laboratory assay. International Research Group on Wood Preservation, Document No. IRGMP 03-10500, 12pp.

Borges, L. M. S., Cragg, S. M., Bergot, J., Williams, J. R., Shayler, B. and Sawyer, G. S. (2008) Laboratory screening of tropical hardwoods for natural resistance to the marine borer Limnoria quadripunctata with an investigation of the role of leachable and non-leachable factors. Holzforschung 62: 99-111.

Borges, L. M. S., Cragg, S. M., Busch S. (2009) A laboratory assay for measuring feeding and mortality of the marine wood-borer Limnoria under forced feeding conditions: a basis for a standard test method. Int. Biodet. Biodeg. 63: 289-296.

Borges, L.M.S., Valente, A. A., Palma, P. and L. Nunes (2010) Changes in the wood boring community in the Tagus Estuary: a case study. Marine Biodiversity Records Vol. 3: e41.

Borges, L. M. S., Merckelbach, L. M., Sampaio, I., Cragg, S. M. (2014A) Diversity, environmental requirements and biogeography of bivalve wood-borers (Teredinidae) in European coastal waters. Frontiers in Zoology 11: 13.

Borges, L. M. S., Mercklebach, L., Cragg, S. M. (2014B) Biogeography of woodboring crustaceans (Isopoda: Limnoriidae) established in European coastal waters. PLoS ONE 9(10): e109593.

Brazier, A (1995) Greenheart and the choice of timbers for marine work: Half day meeting at the Institution of Civil Engineers (maritime board) Tuesday 3 October 1995

British Standard BS EN 275 (1992) Wood preservatives. Determination of the protective effectiveness against marine borers. BSI.

British Standard BS EN 384: 2004 Structural timber - Determination of characteristic values of mechanical properties and density. BSI.

British Standard BS EN 408: 2003 Timber structures - Structural timber and glued laminated timber -Determination of some physical and mechanical properties. BSI.

Castello' J. (2011) The genus Limnoria (Limnoriidae, Isopoda, Crustacea) in Europe, including a key to species. Zootaxa 2968: 1-25.

Cohen, A. N., Carlton, J. T. (1995) Biological study: non-indigenous aquatic species in a United States estuary: a case study of the biological invasions of the San Francisco Bay and delta. University of California Final Report, National Technical Information Service, Springfield, VA, 203 pp.

Cowen C. J. (1979) Timber Trades Journal Hardwoods Supplement $\left(25^{\text {th }} 081979\right)$.

Cragg, S. M. (1996) Timber in the marine environment. Timber Trades Journal, 376: 26-28. 
Cragg, S. M. (2003) Marine wood boring arthropods: ecology, functional anatomy and control measures. In: Goodell T.P., Nicholas B and D.D. Schultz (eds.) Wood deterioration and preservation: advances in our changing world: American Chemical Society, Washington DC. 272-288.

Crossman, M. and Simm, J. (2004) Manual on the use of timber for coastal and fluvial engineering. HR Wallingford.

Desch, H. E. and Dinwoodie, J. M. (1996) Timber, structure, properties, conversion and use. $7^{\text {th }}$ edition. Macmillan Press Limited. London.

Distel, D. L. (2003) The biology of marine wood boring bivalves and their bacteria endosymbionts. In: Goodel, T.P, Nicholas, B, and D. D. Schultz (eds.), Wood deterioration and preservation: advances in our changing world, pp 253-271. American Chemical Society, Washington D.C.

Distel, D. L., Amin, M., Burgoyne, A., Linton, E., Mamangkey, G., Morrill,W., Nove, J., Wood, N., and Yang, J. (2011) Molecular phylogeny of Pholadoidea Lamarck, 1809 supports a single origin for xylotrophy (wood feeding) and xylotrophic bacterial endosymbiosis in Bivalvia. Mol Phylogen Evol 61(2): 245-254.

Eaton R. A. and Hale, M. D. C. (1993) Wood: Decay pests and protection: Chapman and Hall, New York.

Eltringham, S. K. (1971) Factors affecting the distribution of the burrows of the marine wood-boring Isopod Limnoria. International Biodeterioration Vol. 7: 61-67.

Environment Agency Project: SC070083/R1 (2010A) Alternative hardwood timbers for use in marine and fresh water construction. Eds. Williams, J. R., Meaden, M. and J. Simm.

Environment Agency (2010B) The coastal handbook: a guide for all those working on the coast. Bristol: the Environment Agency, June 2010.

Giannakopoulos C., Le Sager, P. (2009) Climatic changes and associated impacts in the Mediterranean resulting from a $2^{0} \mathrm{C}$ degrees global warming. Global Planet Change 68 (3): 209-224.

Gibelin A .L. and De'que, M. (2003) Anthropogenic climate change over the Mediterranean region simulated by a global variable resolution model. Climate Dynamics 20 (4):327-339.

Giorgi, F. and Lionello, P. (2008) Climate change projections for the Mediterranean Region. Global Planet Change 63(2-3):90-104.

Hall G. S. and Saunders R. G (1967) Incidence of marine borers around Britain's coasts. TRADA research report $B / R R / 4$.

Kern M., McGeehan J. E., Streeter S. D., Martin R. N. A., Besser K., and S.M. Cragg (2013) Structural characterization of a unique marine animal family 7 cellobiohydrolase suggests a mechanism of cellulase salt tolerance. Proc. Natl. Acad. Sci. USA 110(25): 10189-94. 
Newton, A. and Mudge, S. M. (2003) Temperature and salinity regimes in a shallow, mesotidal lagoon, the Ria Formosa, Portugal. Estuarine, Shelf and Coastal Science, 56: $1-13$

Oliver, A. C. And Woods, R. P. (1959) The resistance of certain timbers in sea defence groynes to shingle abrasion. The Timber Development Association (TDA) Test Record B/TR/4.

Paalvast, P., van der Velde, G. (2011) New threats of an old enemy: the distribution of the shipworm Teredo navalis L. (Bivalvia: Teredinidae) related to climate change in the Port of Rotterdam area, the Netherlands. Maritime Pollution Bulletin 62(8):18221829

Paalvast, P., and van der Velde, G. (2014) Long term anthropogenic changes and ecosystem service consequences in the northern part of the complex Rhine-Meuse estuarine system. Ocean and Coastal Management, 92:50-64 .

Parmesan, C. and Yole, G. (2003) A global coherent fingerprint of climate change impacts across natural systems. Nature 421: 37-42.

Personal communication (2015) Bournemouth Borough Council. David Harlow Principal Engineer (coast protection) Technical Services Division. Bournemouth Borough Council.

Plaster S. E. M. and Sawyer G. S. (1998) A survey to assess the current and future usage of timber in British port structures. Journal of the Institute of Wood Science Vol 14. No. 6 (Issue 84) 1998.

Praël, A., Cragg, S. M. \& Eaton, R. A. (1999) Development of a novel approach to testing of wood preservatives for marine use: effects of temperature on feeding rates of Limnoria. International Research Group on Wood Preservation IRG/WP/99-10325.

Rivadeneira, M. M. and Fernandez, M. (2005) Shifts in southern end points of distribution in rocky intertidal species along the south-eastern Pacific Coast. Journal of Biogeography 32, 203-209.

Sanchez, E. and Gallardo, C. (2004) Future climate extreme events in the Mediterranean simulated by a regional climate model: a first approach. Glob Planet Change 44 (1-4):163-180.

Sawyer, G. S. and Williams, J. R. (2005) An investigation to assess the feasibility of developing an accelerated laboratory test to determine the abrasion resistance of lesser-used timber species for use in marine construction. International Research Group on Wood Preservation. IRG/WP 05- 20317.

Shipway, J. R., Borges, L. M. S., Muller, J. and S. M. Cragg (2014) The broadcast spawning Caribbean shipworm, Teredothyra dominicensis (Bivalvia, Teredinidae), has invaded and become established in the eastern Mediterranean Sea. Biological Invasions DOI 10.1007/s10530-014-0646-9.

Skaar, C. (1988) Wood - water relations. Springer - Verlag Berlin. 
Turner, R. D., 1966. A Survey and Illustrated Catalogue of the Teredinidae. Museum of Comparative Zoology, Harvard University, Cambridge.

Williams, J. R., Sawyer, G. S., Cragg, S. M. And Simm, J. (2004A) A questionnaire survey to establish the perceptions of UK specifiers concerning the key material attributes of timber for use in marine and fresh water construction. International Research Group on Wood Preservation. IRG/WP 04-10519.

Williams, J. R., S. M. Cragg, Borges, L. M. S and Icely, J. D. (2004B) Marine exposure assessment of the natural resistance of a number of lesser known species of tropical hardwoods to teredinid and limnoriid borers. International Research Group on Wood Preservation. IRG/WP 04-10520.

Wykes, C., Cragg, S.M. and Pitman, A. J. (1997) The functional anatomy of the digestive caecae and gut residence times for the marine borer Limnoria (Crustacea: Isopoda). International Research Group on Wood Preservation IRG/WP/97-10204, 12pp. 
List of figures:

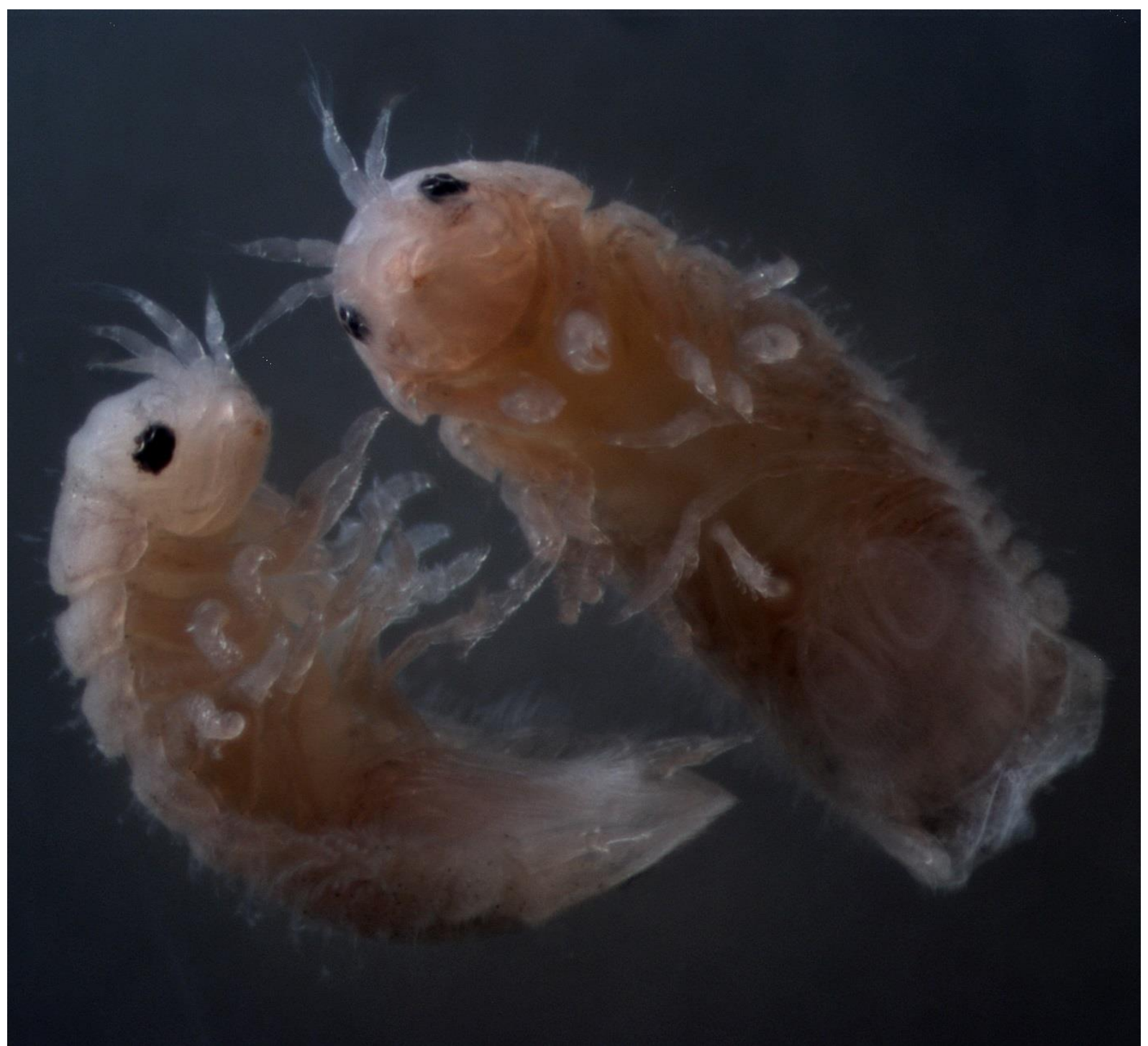

Figure 1: Specimens of Limnoria quadripunctata. Ventral view. 


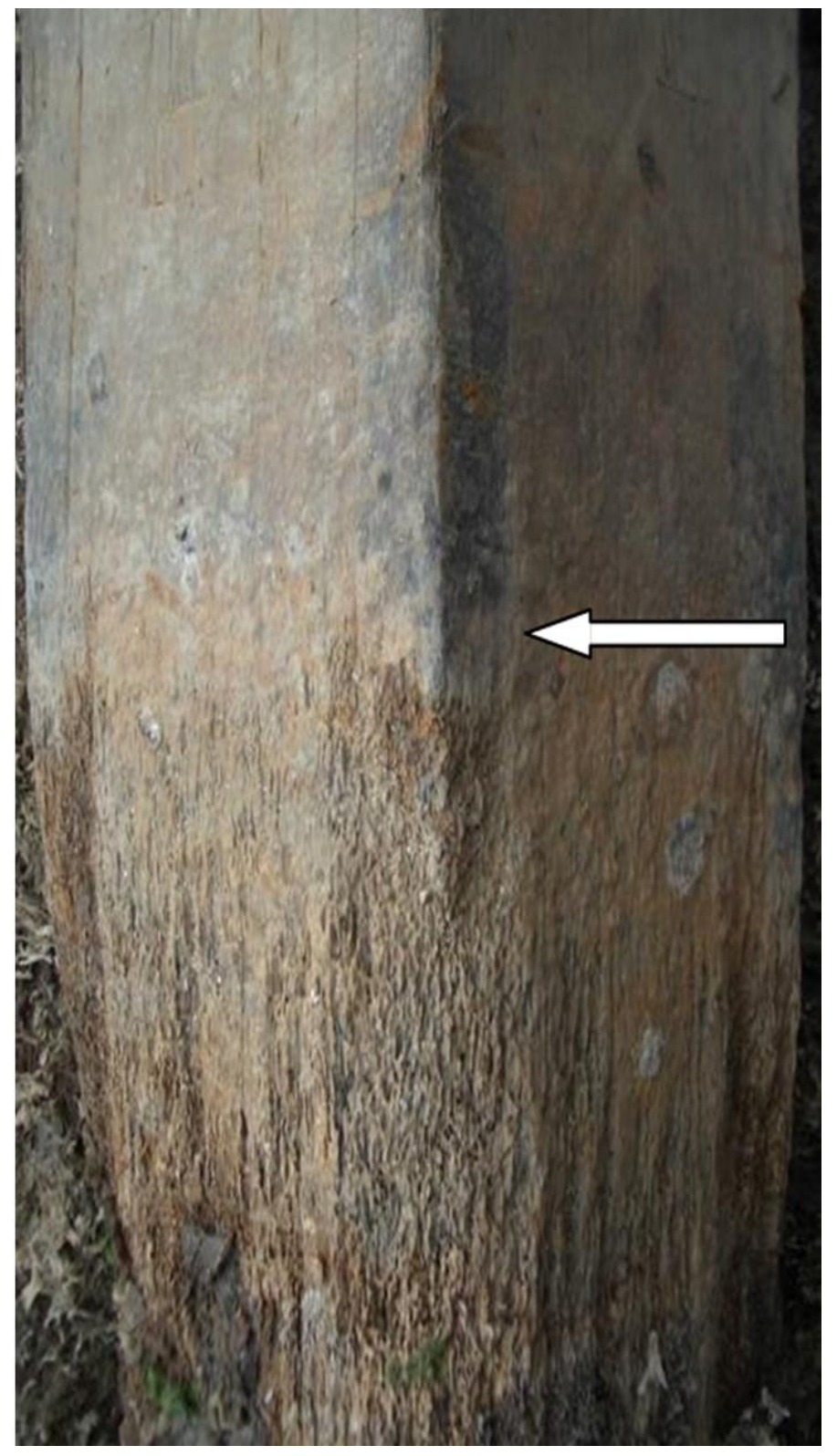

Figure 2: Waisting of timber pile, i.e. it develops a waist (or a pencil point shape) in the intertidal zone, caused by limnoriid attack. Note that there is no attack below the sea bed line which is indicated by the arrow. 


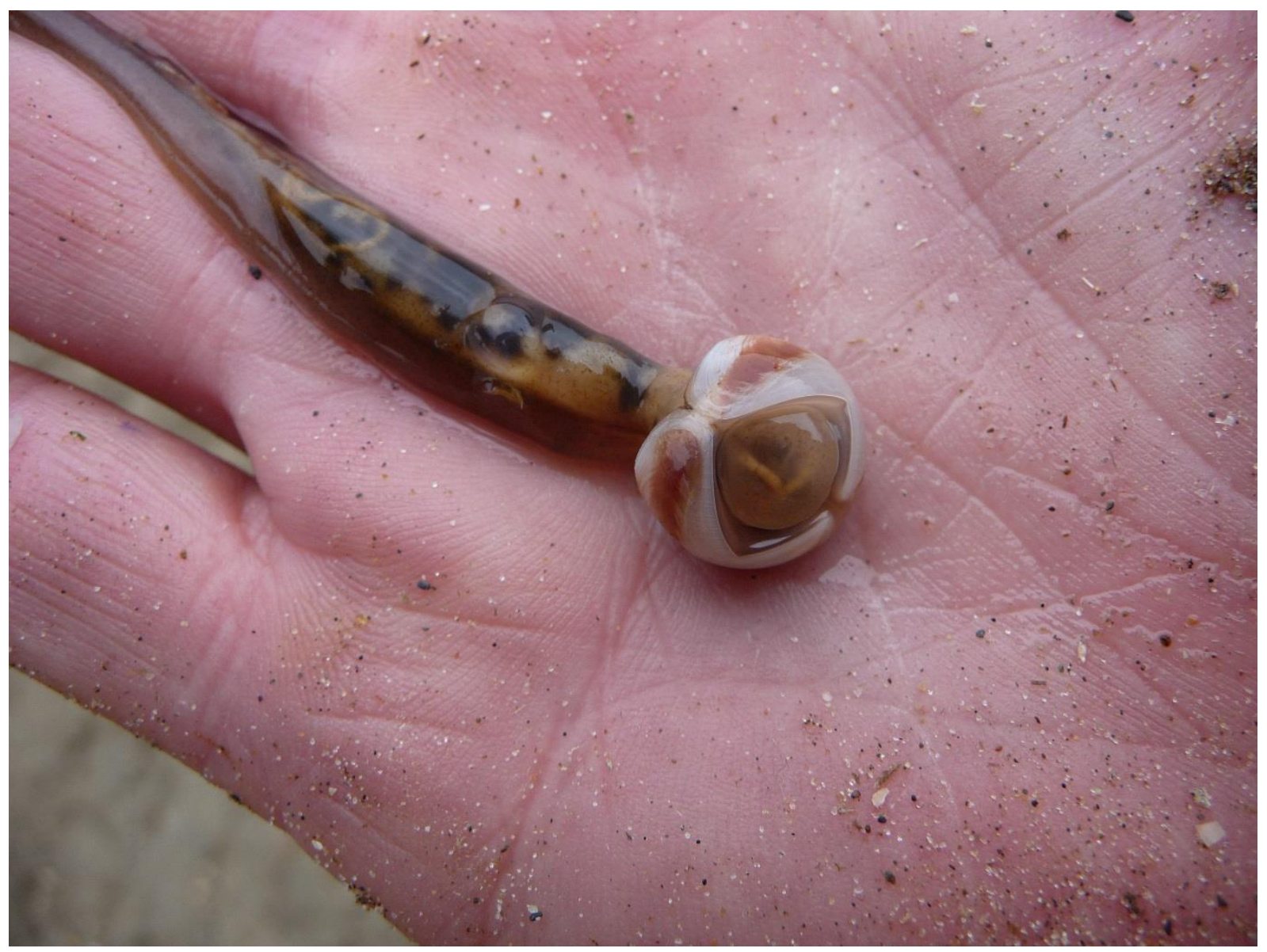

Figure 3: Teredinid extracted from a Douglas fir waling of the Barmouth viaduct within the intertidal zone of the estuary mouth of the River Mawddach, Gwynedd. 


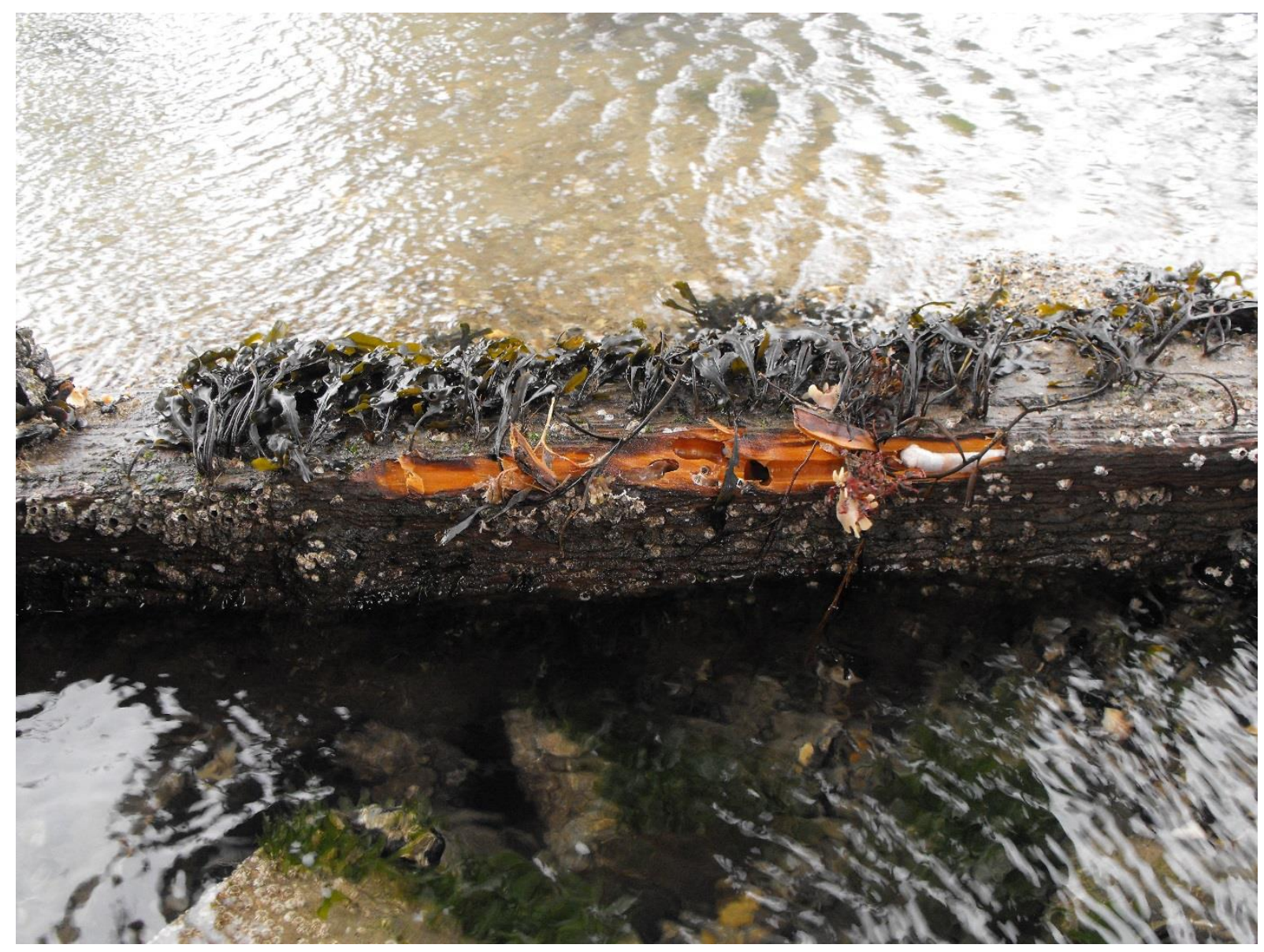

Figure 4: Example of the typical damage caused by teredinids 


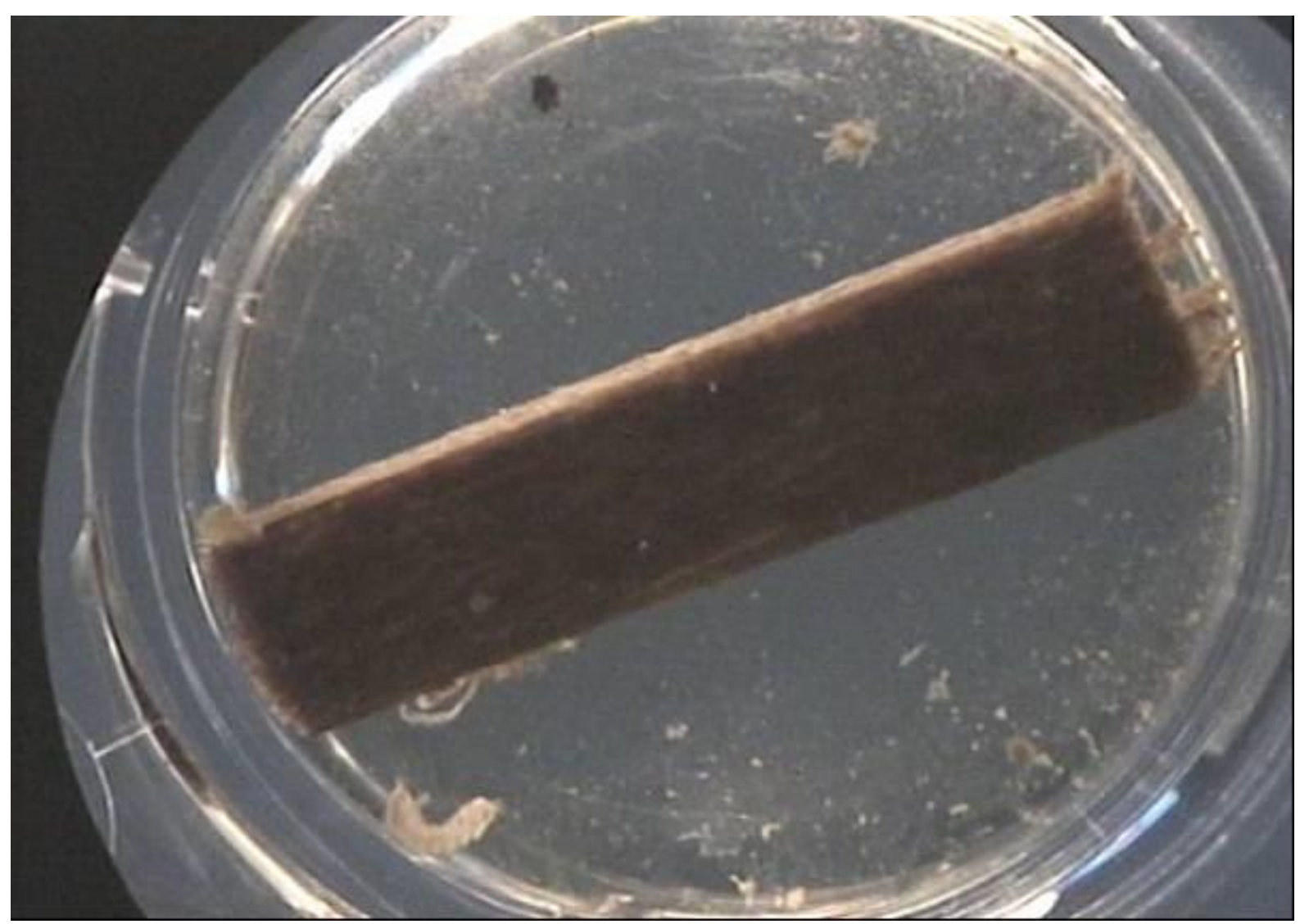

Figure 5: Low feeding rate observed in a chamber containing a stick of ekki and a limnoriid. In this case, ingestion of wood has killed the limnoriid.

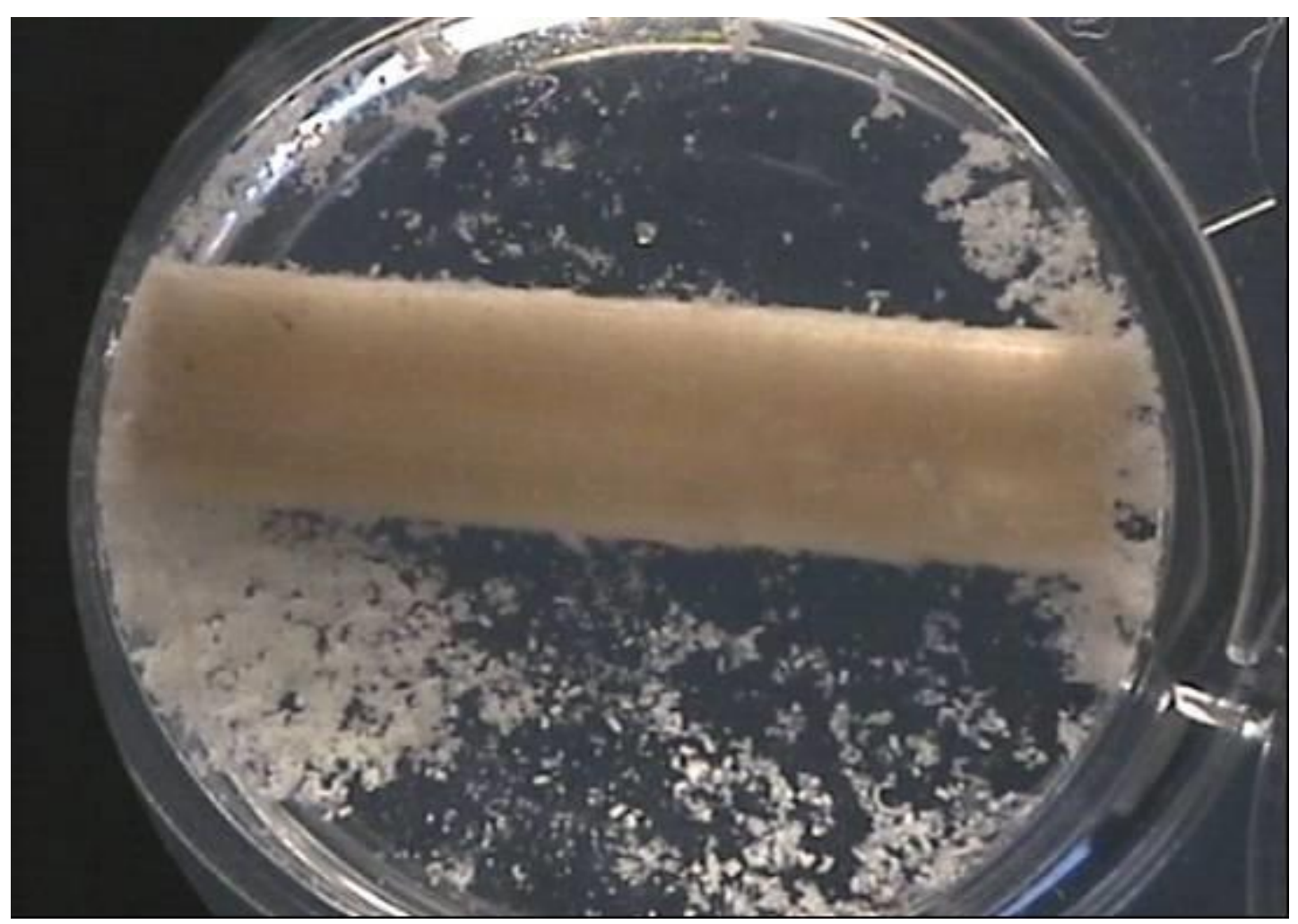

Figure 6: High feeding rate observed in a chamber containing a stick of European redwood sapwood which confirmed the vigour of the limnoriid population. 


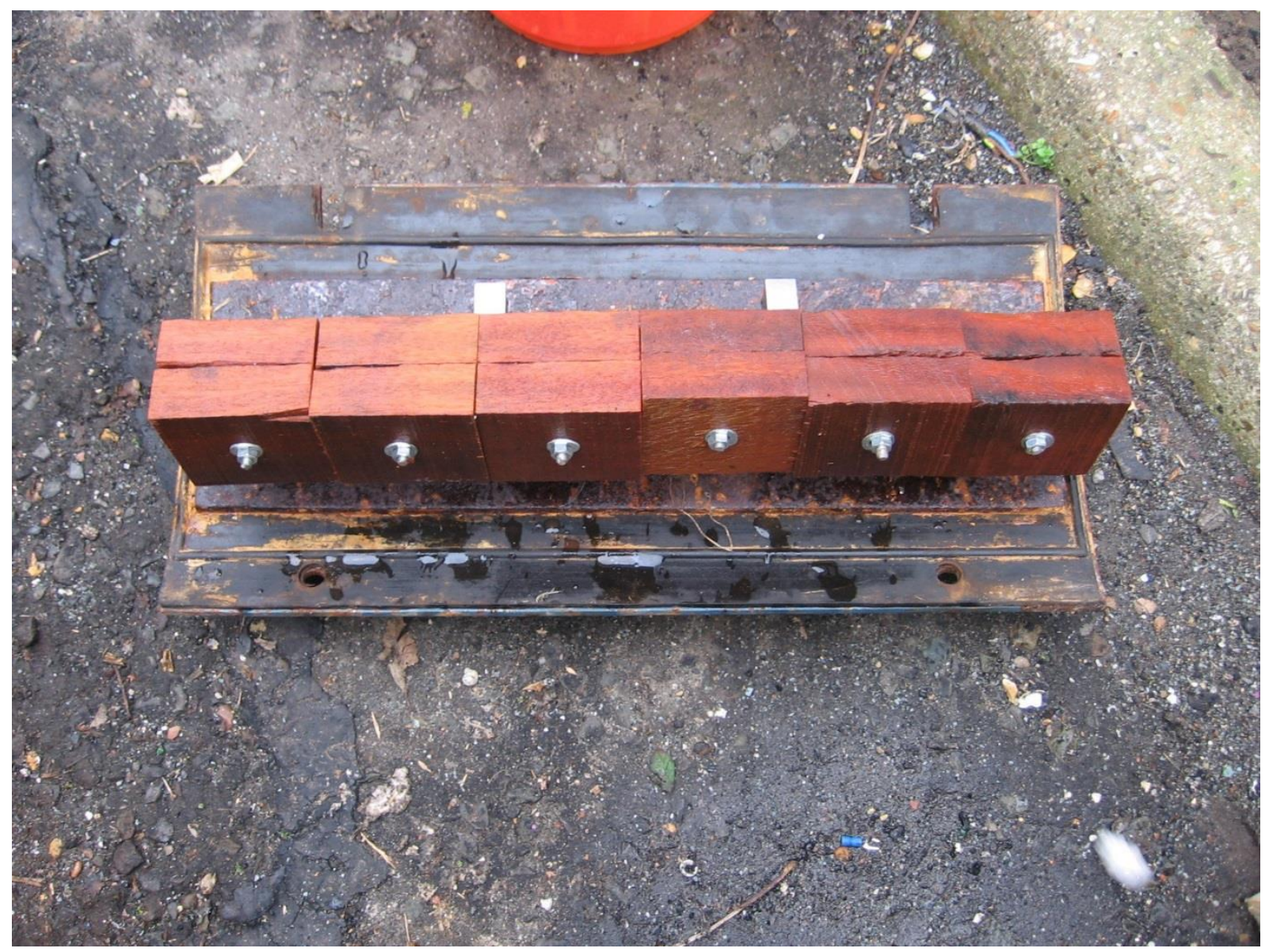

Figure 7: Typical test frame illustrating the arrangement of test blocks prior to the start of the experiment. 


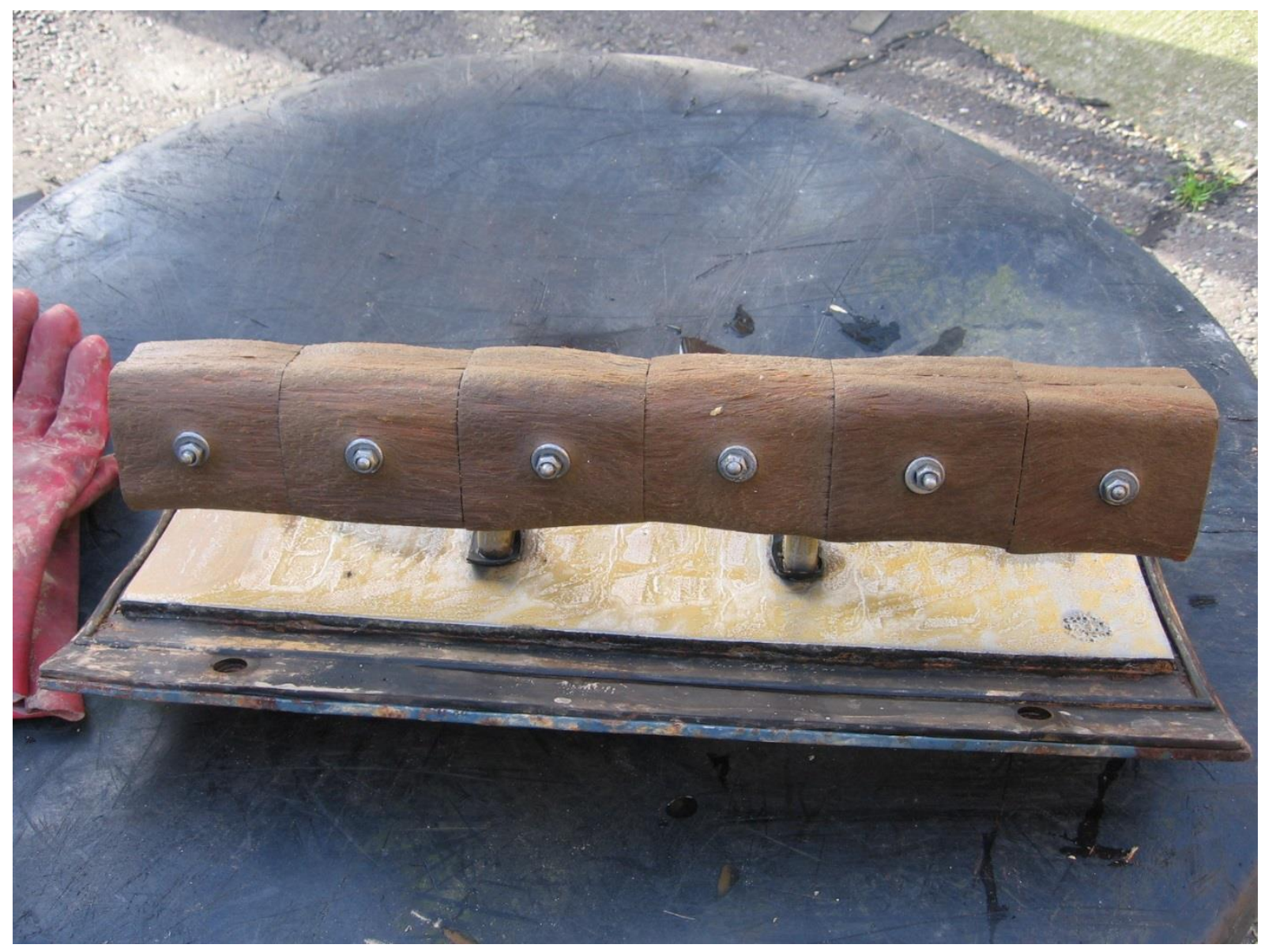

Figure 8: A test frame holding eroded greenheart test blocks after 160,000 revolutions. 


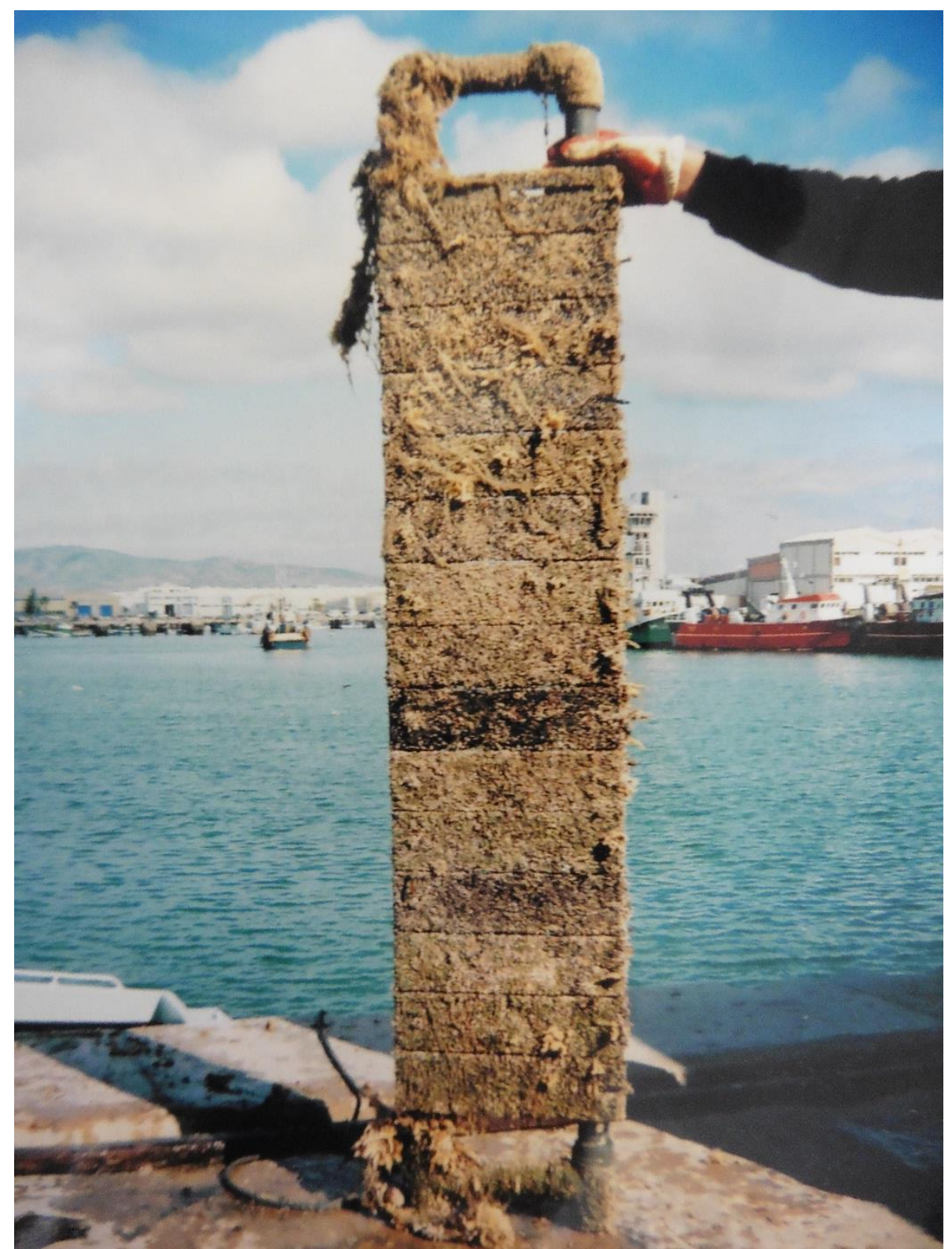

Figure 9: Typical marine fouling on a number of test racks after six months immersion. 


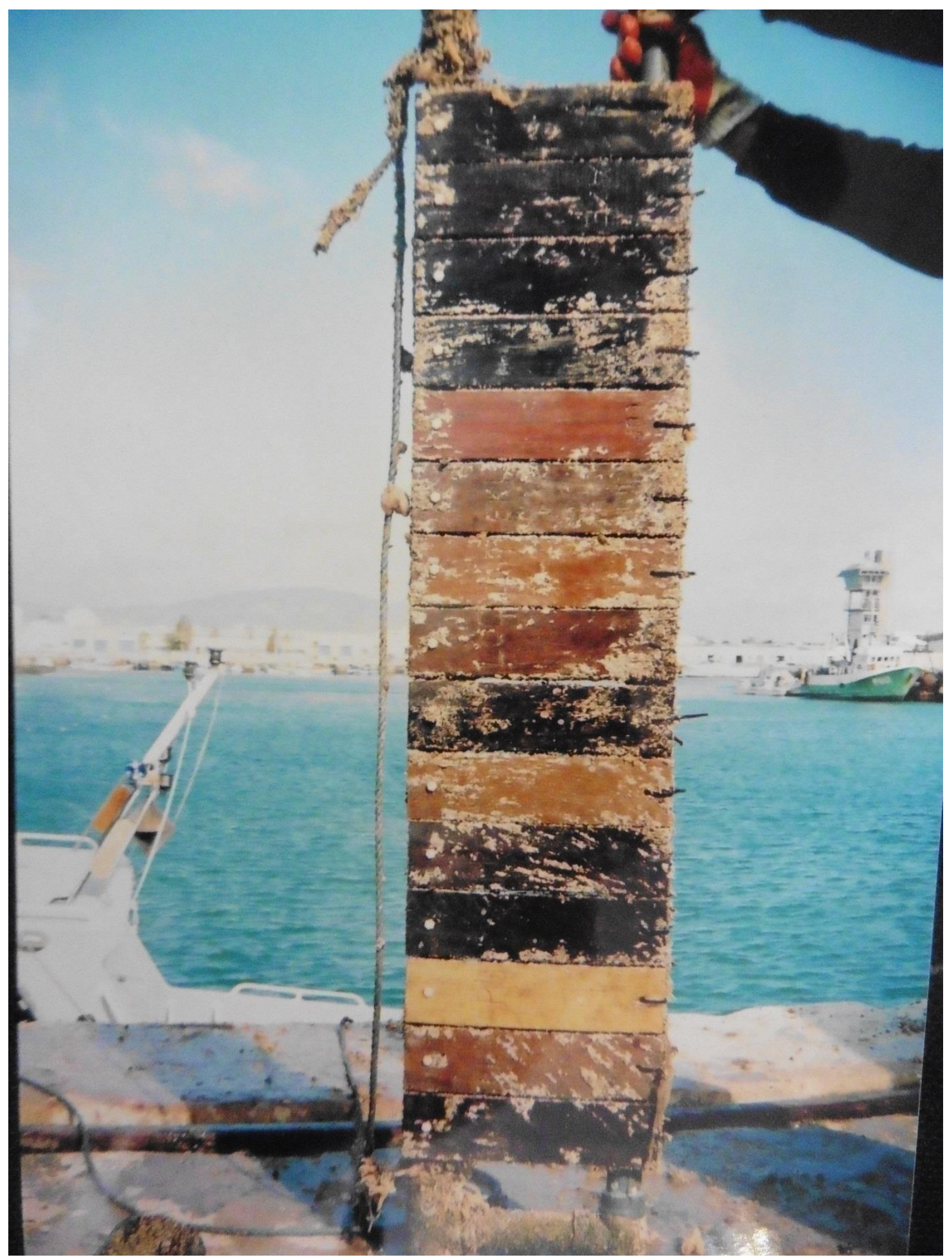

Figure 10: General appearance of test racks after cleaning to facilitate $X$ ray photography. 


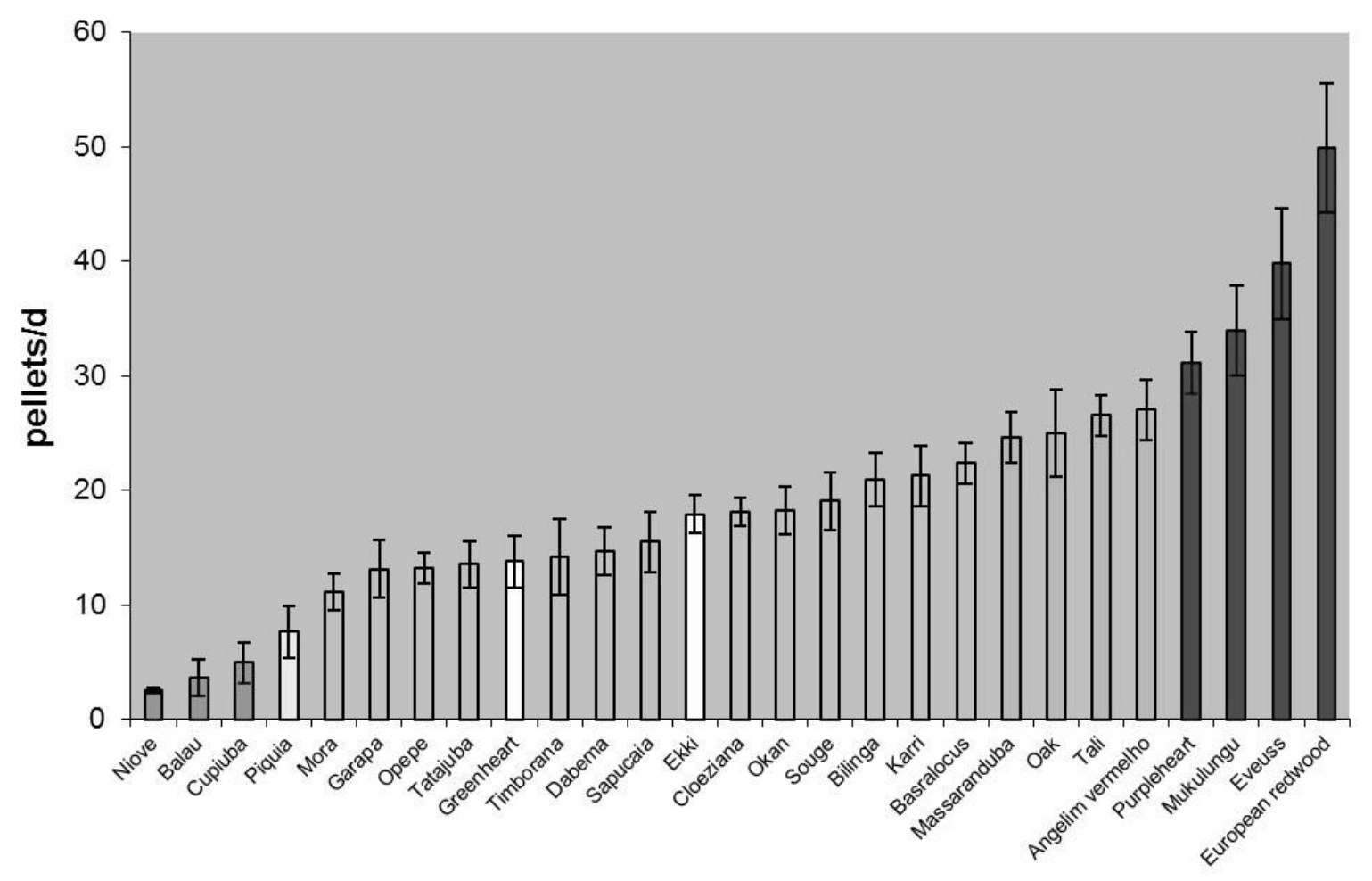

Figure 11: Average daily feeding rates of limnoriids recorded on test timbers..

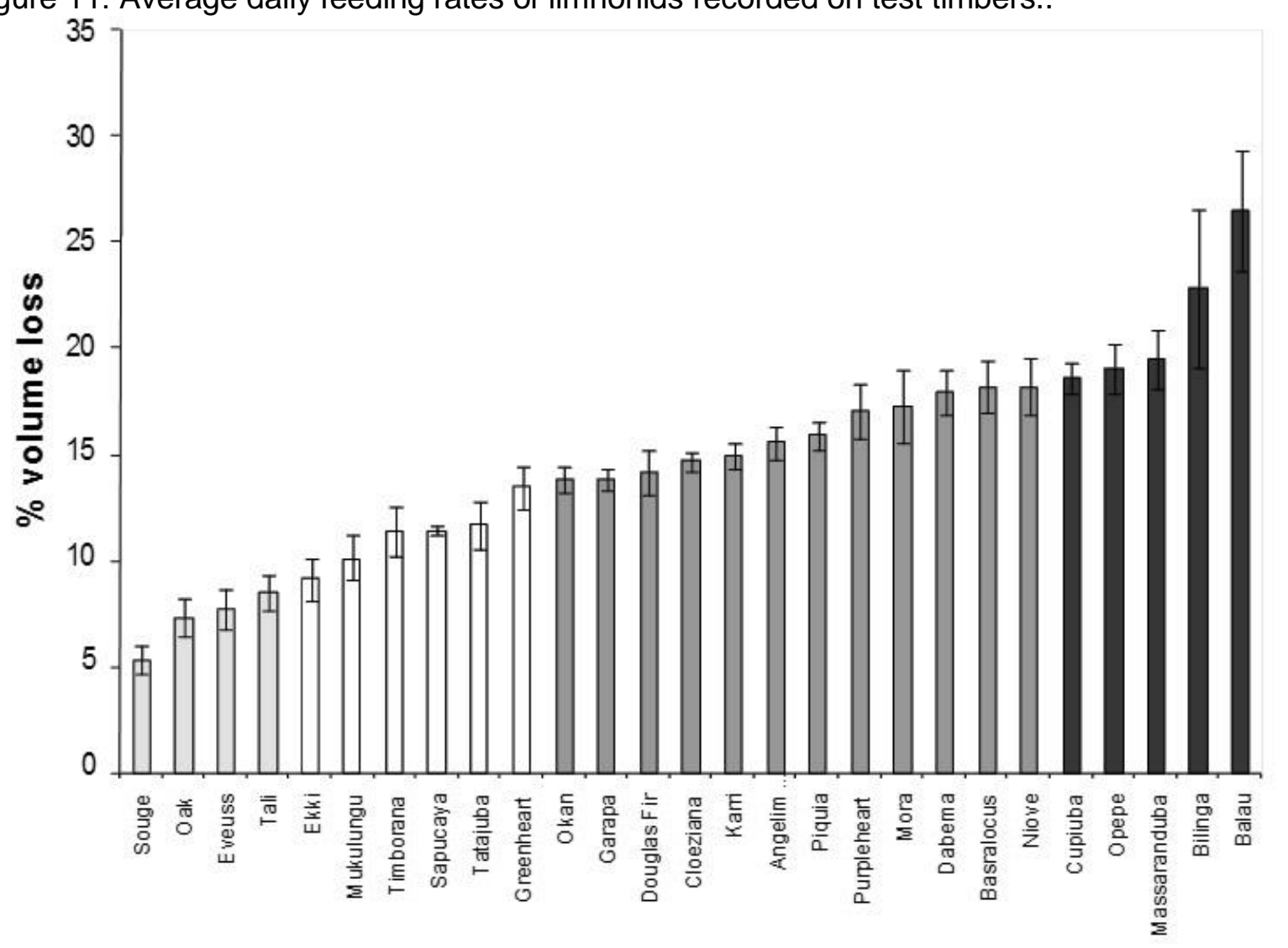

Figure 12: Average loss in volume recorded on test timbers 


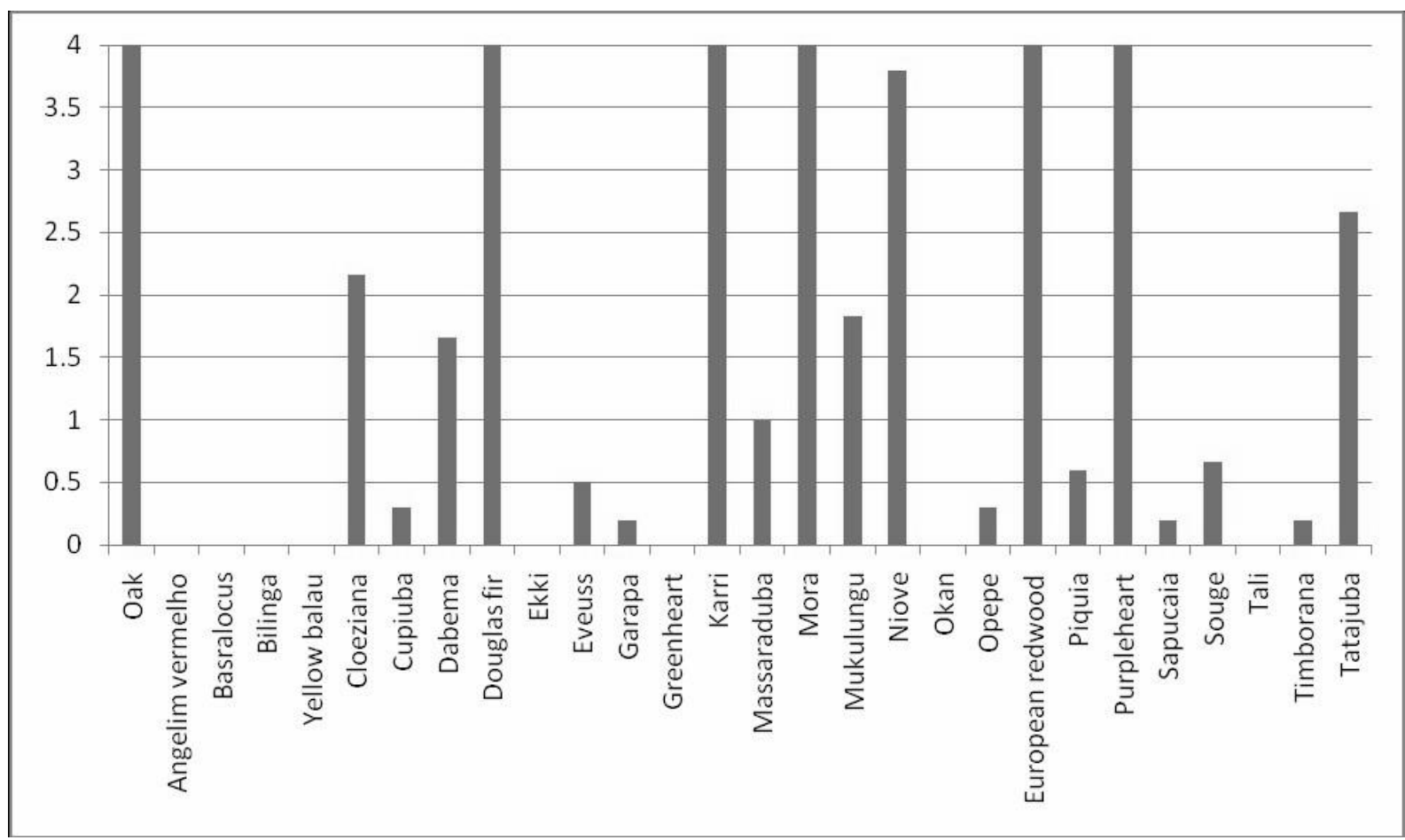

Figure 13: Mean visual assessment ratings recorded after18 months exposure. 


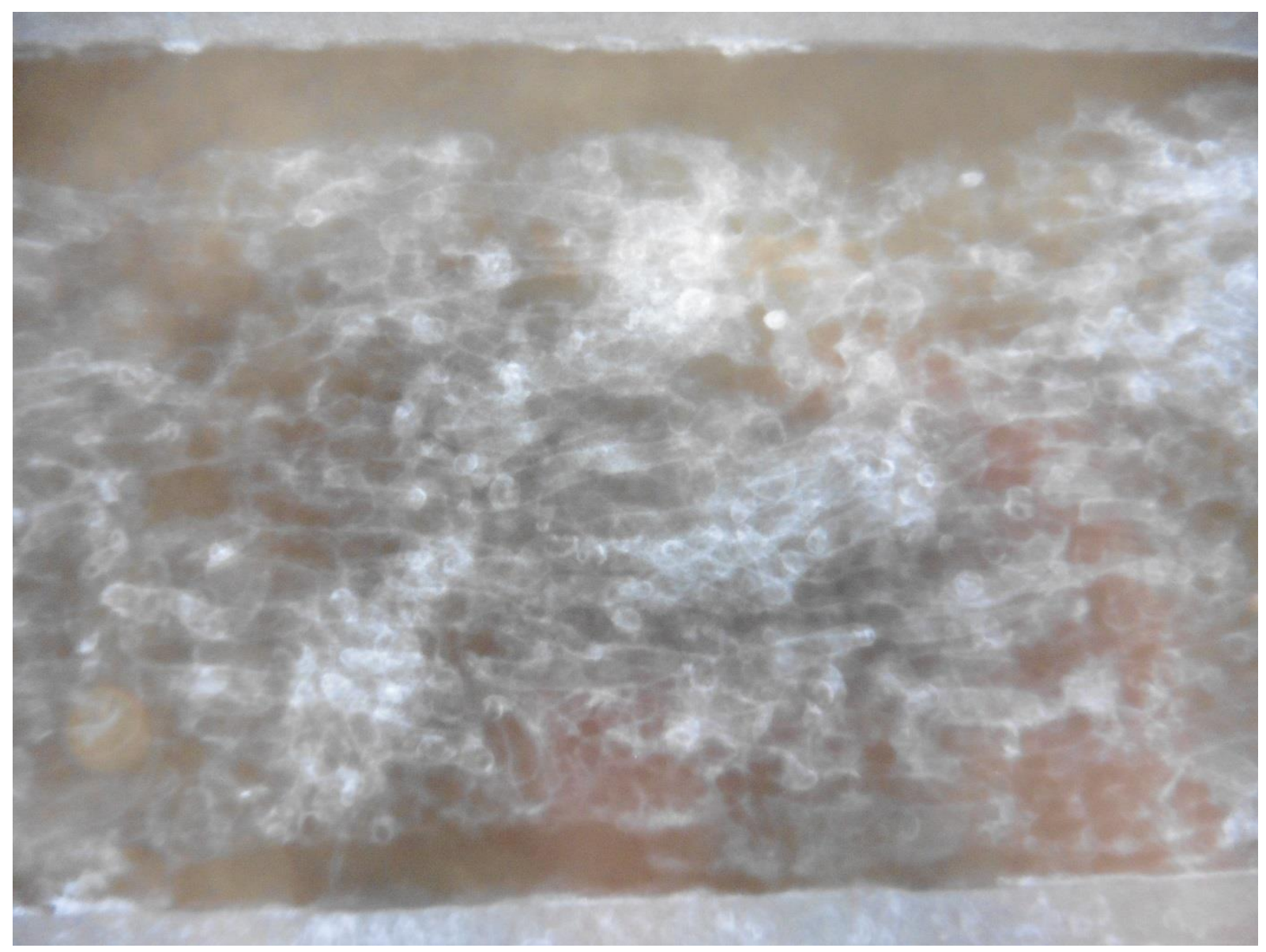

Figure 14: Extensive teredinid attack in a control specimen of European redwood of detected by X-ray photography. The extensive damage confirms the presence of an aggressive teredinid population in the Ria Formosa lagoon and validates the marine trial. 
Figure 15: No evidence of teredinid attack in a specimen of the LUS angelim vermelho. 